\title{
Somalia
}

\section{An Anti-Thesis of the Western Conception of Failed States?}

\author{
Ransford Edward van Gyampo \\ Department of Political Science \\ University of Ghana, Legon \\ Accra, Ghana \\ Email:vangyampo@yahoo.com/revgyampo@ug.edu.gh \\ DOI: http://dx.doi.org/10.4314/gjds.v8i2.1
}

\begin{abstract}
"Failed States" do not necessarily produce terrorists as the evidence from Somalia clearly shows. Regrettably, the fight against terrorists often posits a causal nexus between "Failed States" and terrorism. Even though there may be some iota of truth in this claim, it is essentially a parochial as well as reductionist view that does not allow the emergence of locally evolved legitimate authority like the Union of Islamic Courts to deal with issues of security. This paper reviews the concept of failed states and its supposed results of anarchy, conflict and safe-haven for terrorists. Using the US policy towards Somalia as a case study, it points out the flaws in the concept of "Failed States" and argues that these flaws when not fully dealt with, may affect any meaningful global effort to counter terrorism and to deal with human security issues that arise as a state is classified as "failed" or "collapsed".
\end{abstract}

Keywords: Failed States, Anarchy, Conflict, Safe-Haven, Human Security, Terrorism

\section{Introduction}

In recent times, several states, especially of the Third World, have encountered serious difficulties in the discharge of their core functions such as maintaining law and order, enabling development and guaranteeing territorial integrity. Some, particularly in Africa, have even undergone experienced total disappearance of central authority or "state collapse". Countries facing such crisis have been labeled "Failed States." In the Western sense, "Failed States" are equated with chronic anarchy, exportation of terrorism, instability, total economic collapse and humanitarian crisis with its attendant fall-out in the form of global security. However, this conception is myopic, simplistic and does not promote any meaningful and serious attempts to fully deal with issues related to human security in countries perceived as "Failed States." 
The Western conception of "Failed States" draws heavily on the dramatic developments in Afghanistan between 1994 and 2001. In the context of the Global War on Terror (GWOT), the Taliban's rise to power from the ashes of a collapsed state, and their subsequent alliance with Al-Qaeda, has come to be regarded as a terrifying, unrepeatable experience, legitimizing a security-centered, interventionist stance towards states labeled "failed" by the Western or American-led international community.

This article adopts a very skeptical approach to the Western conception of "Failed States." Its conceptual framework draws strongly upon critiques directed by Duffield (2001) towards the myth of the "End of History" and liberal governance. The Western conception of "Failed States" is not an apolitical account, as many authors claim, but a discursive attempt to naturalize the hegemony of a very ideological political-economic project. Indeed, the analysis of who has failed and who has not, of why failure occurs and which dynamics sustain it, of what reality on the ground looks like in collapsed states, and of how the international community should react to state-failure, is very political. The dominant perspective overlooks a whole array of theoretical complexities and empirical nuances. Given liberal market democracy's nigh complete triumph, failing states are regarded by the West as dangerous aberrations in the global village. But this is a perilous over-simplification.

A second important theoretical influence comes from authors like Doornbos (2002) and Menkhaus (2004) who offer an alternative, non-dogmatic appraisal of state-failure. This article by no means suggests that failed states are not a security problem, or that the human security situation in collapsed states does justice to the rights and aspirations of local people. It does, however, seek far more dynamic, critical and nuanced engagements with "Failed States" than have hitherto been dominant in academic literature and international policy. It explicitly chooses to be non-deterministic by not considering the state as an eternal given, but rather one of many forms that legitimate political authority can take, and security is explicitly interpreted. A more holistic, non-statecentric perspective allows us to appreciate the (dis)advantages of "governance without government" more on its own terms and to consider livelihoods and substantive freedoms from the perspective of communities and the individual. Moreover, such an approach is more in keeping with the socio-historical complexities of Somali society than classical lenses.

This article argues that the international community's conception of state failure or collapse hinders the re-emergence of legitimate authority and bottom-up responses to human security in Somalia. As the US-Somalia relations is analyzed after September 11, this paper points out quite clearly the theoretical flaws underpinning the Western conception of "Failed States" and the implications of such reductionist view on the humanitarian situation in the Horn of Africa. 


\section{Interrogating the Western Conception of Failed States}

After the demise of communism following the end of the Cold War, it was argued that liberal democracy would increase the interdependence between countries and serve to promote global peace (Fukuyama, 1992). However, new threats of anarchy have arisen across the Global South. There have been ethnic conflicts leading to many internally displaced persons as well as disease, poverty and hunger. Consequently, the expectations of a globally peaceful world have been a chimera even as the international community has been unsuccessful in dealing adequately with security and humanitarian challenges (Kaplan, 1996).

In dealing with this threat of anarchy, the Western conception of "Failed States" has posited that the problems of the Global South are peculiar to individual countries. Indeed, that conception ignores the fact that structural imbalances in the world economy and Western power politics might be destabilizing the South. Instead, it emphasizes the growing incapacity of postcolonial states to respond autonomously to old and new challenges in a changing environment (Duffield, 2001). Defined by Zartman (1995:5) as states that no longer fulfill basic functions, the so-called failed states were initially understood through a humanitarian prism of economic anarchy and famine in the absence of centralized government. However, as the international climate changed dramatically in 2001following the World Trade Centre attacks, local worries about refugee fluxes and disappearing livelihoods suddenly acquired international significance. Afghanistan's collapsed state was identified as the safe haven for Al-Qaeda's devastating attacks. The Bush administration swore to hunt down the terrorists; and large segments of the American political - academic establishment duly replied by providing an intellectual legitimization for the war on terrorism (Kraxberger, 2007).

Notwithstanding the idea that chaos in the South was essentially caused by internal factors needing internal handling, the sacrosanct principle of state sovereignty was jettisoned. Indeed, due to the proliferation of cosmopolitan interpretations of human rights, it has been increasingly recognized that the UN's obligation to guarantee basic freedoms trumps national autonomy and that humanitarian intervention to uphold them is legitimate (Ignatieff, 2003). Again, as the geopolitical tide turned, the West became increasingly assertive. The year 1989 marked the beginning of America's status as a superpower in a uni-polar world and bestowed on it an unprecedented freedom to pursue its objectives. Simultaneously, due to instability along its borders, the EU faced domestic pressures to react to faltering states in its neighborhood. Thus, the absolute character of the notion of non-interference in countries' internal affairs was put on the defensive, and the fusion of liberal idealism and Western self-interest paved the way for a new interventionism (Fearon and Laitin, 2004).

The central argument of what is termed as the Western Conception of "Failed States" is that failed states creates serious hurdles for globalization and that before liberal democracy can triumph, all efforts must be put in place to wage a global war against 
the nihilist forces of terror. Recall that after 1989, former superpower proxies lost vital support needed to prop up their patronage-based regimes. This exacerbated central authorities' already feeble capacity and reduced their willingness to provide a minimum of public goods to their population, including security (Rotberg, 2004). From Sierra Leone to Nepal, states lost their monopoly on violence as domestic politics acquired zero-sum characteristics and began withdrawing from peripheral areas. Theorists on the war on terrorism argue that these internal dynamics of state-failure converged with worrying international trends. Indeed, after the end of the Cold War, the US demonstrated growing unwillingness to bring law and order to an anarchical international society. The Clinton Administration's so-called "dangerous passivity" was contrived to mean that drugstraffickers, arms-dealers and, above all, Islamist fanatics were given leeway to develop bases in the no man's land that collapsed/failing states had abandoned and that when left alone, the "black holes" would constitute grave threats to global security (Frum \& Perle, 2003).

Afghanistan plays a central role in the "Failed-States-Conflict-Terrorism" nexus. Following years of intense fighting between the Soviet-backed government and the Mujahedin, a free-for-all civil war broke out after Moscow's withdrawal. What remained of the once centralized Afghani state withered away quickly as warlords carved up the territory and dismantled formal political institutions; Kabul's monopoly on violence and taxation were privatized (Center for Global Development, 2004). To fund their militias, Afghani warlords turned increasingly towards opium and predation of the local population. The delivery of Weberian public goods like basic security and administration was abandoned entirely and Afghanistan's narco-agriculture was integrated into the global black economy. The vacuum of authority was filled by the militant Taliban who combined the promise of Sharian justice with swift re-imposition of order in conquered regions (Rashid, 2001). By 1997, most of the territory was pacified, with the Taliban imposing a fundamentalist form of Islam to unify an ethnically torn nation (ibid). Despite the continued reliance of the new power-holders on opium production as their main income base, the international community by and large continued to ignore Afghanistan. Donors agreed that it was a humanitarian tragedy, but regarded the country as holding limited strategic value; and even after the Taliban invited their ideological fellow-travelers, Al-Qaeda, to establish training camps, little changed (ibid). Thousands of international volunteers poured into Afghani bases, providing Bin Laden with ample human resources, financial reserves and military expertise to prepare his global jihad against the United States America (ibid).

For theorists on the war on terrorism, Afghanistan and the events of 11 September $2001^{1}$ demonstrated that there is only one remedy for this problem: military confrontation

1 The September 11 attacks, often referred to as September 11 th or 9/11 (pronounced as "nine eleven"), were a series of coordinated suicide attacks by al-Qaeda upon the United States on September 11, 2001. On that morning, 19 al-Qaeda terrorists hijacked four commercial passenger jet airliners. The hijackers intentionally crashed two of the airliners into the Twin Towers of the World Trade Center in New York City, killing everyone on board and many others working in the buildings. Both towers collapsed within two hours, destroying nearby buildings and damaging others. The hijackers crashed a third airliner into The

$4 \quad$ GJDS, Vol. 8, No. 2, October, 2011 
with the quintessentially unappeasable terrorists and their local henchmen before they strike again. This core strategy is complemented by forging ever tighter links between development and security, as aid money is used to develop potential terrorist safe-havens and bolster America's regional allies, not to help needy but "unstrategic" countries (Berger \& Borer, 2007).

In the Bush Administration's neoconservative world-vision, the long-term solution to reversing state-failure lies in the aforementioned wizardry of "End of History" (Fukuyama, 1992): reviving a minimalist, pro-Western state, which embraces neoliberal globalization, the magic of laissez-faire and electoral democracy. For neoconservatives, a "lean" state, private property and deregulated marketplace are entirely natural-de facto a-political - and universal, and hence perfectly exportable via military force and imposable via decree by "Green Zone" technocrats. Convinced of the Muslim World's thirst for "freedom", the Bush administration assumed that military walkovers in Afghanistan and Iraq could be translated into political triumphs as power would be handed over swiftly to Western minded elites after America's pro-consul had drawn up the "neutral" framework of market-democracy (Frum \& Perle, 2003).

This article does not suggest that the Western conception of "Failed States" is an American monopoly. Indeed, European countries, led by Britain, have echoed the neoconservative discourse and contributed extensively to casting failed states as "black holes" associated with threats such as organized crime, terrorism, regional instability, cross border drug trafficking, illegal migration and illegal arms trading among others (Solana, 2003). Overall then, a coalition of Western protagonists has taken the lead in portraying failed states as one of the biggest threats to world peace and global prosperity. Through the systematic reproduction of alarmist discourse, failed states are constantly, and often without much empirical evidence or regional differentiation, associated with "terrorism", "anarchy" and "instability" (Winkler, 2006). The weakening or absence of central government structures in some parts of this world is regarded as extremely dangerous, and intuitive arguments about the security risks of "vacuums of authority" abound.

\section{The War on Terrorism: Evidence from Somalia, a Failed State}

The Somali state became anarchic in 1991, following decades of Siyad Barre's rapacious rule. This led to the proliferation of several militias and trading became largely impossible. Images of starving children and inter-factional massacres triggered a UN humanitarian intervention (Operation Restore Hope) to save life, property and restore calm in Somalia. However, this quickly turned into a nightmare as UN troops inadvertently became

Pentagon in Arlington, Virginia, just outside Washington, D.C. The fourth plane crashed into a field near Shanksville in rural Pennsylvania after some of its passengers and flight crew attempted to retake control of the plane, which the hijackers had redirected toward Washington, D.C. to target either the Capitol Building or the White House. There were no survivors from any of the flights. Nearly 3,00o victims and the 19 hijackers died in the attacks. 
involved in the impossibly complex meanderings of Somali inter-clan politics (Ahmed \& Green, 1999). Ignorant and oblivious of how hostile Somali clans are to central authority, a naive international community blundered as it tried to restructure local power configurations. After the slaughter of 18 American marines, the United Nations Operation in Somalia (UNOSOM) withdrew from a country that subsequently vanished off Western radar-screens (ibid). For the outside world, Somalia became synonymous with roadblocks, gun-toting youngsters and total lawlessness. Warlords carved up the territory, engaged in endless micro-conflicts and seemingly suffocated all commercial activity. While 14 UN-sponsored attempts to reconcile the nation failed, a permanent humanitarian crisis ensured Somalis topped all global deprivation indices (ibid). Somalia indeed, became the archetype of state collapse.

\section{The Islamic Courts}

External intervention, legitimized explicitly by the supposed link between state collapse, religious fanaticism and terrorism, reversed the tangible progress made by the Union of Islamic Courts (UIC), a self-organizing non - state actor, in providing bottom-up answers to human security challenges in an extremely tough environment. The UIC's remarkable rise and fall and, more broadly, the dynamics of Somali Islamism have been subjected to a lot of misunderstanding in recent years. Historically, Islam has been very important to Somali society, but always remained embedded in cultural - traditional practices. The emphasis has been on Sufi-inspired mysticism and pragmatic interpretation of the Quran, not on a literal reading of Islamic doctrine (Lewis, 1998). Crucially, Islam has seldom, if ever, been allowed to trump clan identity and was systematically kept out of politics (ibid). Somalia has thus been extremely infertile ground for religious extremism. The birth of the Islamic Courts in the 1990 s should be situated precisely against this background. In an attempt to restore order and security in Mogadishu, an ad hoc alliance joined forces to disarm the various militias and facilitate trade. While businessmen provided the funds for the Courts and clan elders used their traditional authority to persuade youngsters to disarm, there were flexible interpretations of the Sharia to end the impunity and constant predation (De Waal, 2004). The first generation of Islamic Courts was extremely decentralized, with neighborhoods setting up Courts. Fragmentation had its advantages - their decentralized character made the Courts' decisions more acceptable to the militias and the population - but also meant that inter-clan feuds were still hard to resolve, hampering the free flow of goods and services. Moreover, Mogadishu's powerful warlords were not impressed: the Courts' growing authority challenged warlord hegemony and undermined their lucrative protection rackets. Unsurprisingly, Somalia's private militias counter-attacked and suppressed most proactive Courts; the spontaneous emergence of business-backed Sharia institutions followed by warlord repression (leading to the Courts' temporary disappearance) was a recurring phenomenon between 1994 and 2004 (Marchal, 2004). 
Around 2005, a broad coalition of powerful forces in Mogadishu decided to break the pattern and put a definitive end to anarchy. Once more, dozens of decentralized Courts proliferated, but this time an umbrella structure, the UIC was established. Crucially, the powerful Hawiye clan and Somalia's wealthiest businessmen threw their weight behind the Islamic Courts, as did a whole raft of Islamist charities, fundamentalist groups and local militia. The UIC went far beyond the goals and tactics of its fragmented predecessors and explicitly proclaimed that it wanted to re-unite the whole of Somalia under the banner of Islam, relying on a recipe of Sharia justice and the provision of security and social services. The UIC identified clan divisions as the main culprit for Somalia's state collapse and humanitarian crisis but realized religion would not suffice to unify the country again; however, the embracing of business and militant nationalism as well as the creation of a militia of young, disciplined fighters recruited across clan lines - Al-Shabaab - proved to be an irresistible combination when guided by Pan-Islamic unity (Prunier, 2006).

Despite growing American-Ethiopian backing for the remaining warlords, the UIC swept through Mogadishu and quickly expanded its authority throughout Central Somalia. It gave immediate orders to remove all roadblocks, reopen schools and confiscate all guns. Almost immediately, UIC rule brought very tangible benefits to the population and gave the Islamists the aura of a national liberation movement; human security improved remarkably, as girls went back to school, transaction costs for business shrunk, entire neighborhoods were thoroughly cleaned and Mogadishu's streets became safe again at night (Menkhaus, 2007). As noted earlier, the UIC's rise was less appreciated outside Somalia.

Once more, a religious grassroots movement swore to unite all tribes and to install the rule of law in a failed state. The UIC's alliance with key economic actors, its promise of Sharia justice and its disciplined militants reminded the US of its Afghani nemesis. Moreover, because the CIA suspected the UIC of hosting East African terrorists, the US feared that Al-Qaeda would obtain a new sanctuary and set the Horn ablaze. After the fiasco of the Washington-sponsored "Alliance for the Restoration of Peace and CounterTerrorism" (a loose union of several of Somalia's most corrupt politicians and militialeaders), America turned to the TFG, a secular but self-appointed executive in control of just one town in Central Somalia (Prunier, 2006).

The TFG was not too popular for a number of reasons. First of all, comprising dozens of warlords, it was not only utterly incompetent, but also excluded the Hawiye clan and overrepresented their Darod rivals. Secondly, the TFG had actually been created by Ethiopia, Somalia's arch rival (Samatar, 2007). For outsiders, the rivalry between both countries is hard to comprehend, but the hostility runs very deep. Since independence, it has been a core aim of every ruling faction to unite all Somalis in one country, ending their dispersal over five different states. The largest Diaspora lives in Ethiopia's Ogaden and has always been marginalized by Addis. From 1977-1978, the two countries went to war over the Ogaden, with Somalia emerging as the loser. This torpedoed Somali irredentist dreams and consolidated Ethiopia's regional hegemony (Meredith, 2005). Moreover, most 
Somalis blame Ethiopia for perpetuating their misery and encouraging predatory warlords to keep the country divided. The fact that just about every Somali saw Ethiopian Prime Minister Meles Zenawi's hand behind the TFG's creation delegitimized the transitional executive from the onset for many citizens. America's support for Addis and for the TFG, "to confront the (absent) terrorists", exacerbated matters further and bolstered the Islamists' claims of being the sole legitimate representative of the Somali nation (Kamel, 2007). Months of tense co-existence between the antagonists ensued: while the UIC conquered/liberated half the country and dramatically improved the security situation, the TFG anxiously tried to negotiate power-sharing arrangements. However, at the same time, the TFG's Ethiopian masters steadily stepped up their bellicose rhetoric. The Islamist movement was a broad tent of clan elders, merchants, ultraconservatives and Sufi clerics, but Ethiopia's "failed state-instability-terrorism-Taliban/UIC" discourse undermined any attempt to reach out to moderates who initially outnumbered the radicals within UIC ranks. Addis accused the Courts of allying with Wahhabi extremists and Eritrea, and sent troops into Somalia to lure trigger-happy jihadists into military confrontation (Gettleman, 2006).

While important parts of the UIC, especially, its military wing might not have been trained by Al-Qaeda in Afghanistan, it certainly harbored sympathies for a Pan-Islamic Caliphate, preaching holy war against Ethiopia (though not America). Some Islamist leaders were deliberately ambiguous about their irredentist and jihadist goals and pushed some Courts to apply Sharia with increasing puritanical vigor. Nevertheless, the UIC's dominant moderate/pragmatic current continuously signaled its preparedness for power-sharing in a united Somalia. Had the international community and Addis really wanted to make a comprehensive peace deal, they probably could have obtained one (Kamel, 2007). However, Ethiopia was simply not interested. Its government was seeking open war to distract attention from internal problems. Meles Zenawi's reign is increasingly being challenged by a vociferous opposition and demands from Ethiopia's peripheral regions to end their structural marginalization are growing ever louder. Moreover, Addis was determined to do whatever was necessary to stop a united, Islamist Somalia from re-emerging and challenging its regional hegemony; the prospect of a potential axis Mogadishu-Asmara, supporting Ethiopian rebels, terrified Meles' regime (ibid).

Ethiopia's cunning discourse that painted the Islamic Courts as Somalia's NeoTaliban masterfully played into Washington's fears and got it all the support it wanted. Despite the fact that most Somali experts dismissed the UIC-Al-Qaeda link and estimated the number of international terror-suspects on Somali territory to be no more than half a dozen (Menkhaus, 2007), the CIA and State Department gave Meles the green light to combat terror, as a regional proxy-conflict of the war 
on terrorism. In the words of the Assistant Secretary of State for African Affairs:

We remain deeply troubled that foreign terrorists associated with alQaida have succeeded in establishing a safe haven in Somalia. Somalia's continued exploitation by terrorist elements threatens the stability of the entire Horn of Africa. We will therefore take strong measures to deny terrorists safe haven in Somalia, as well as the ability to plan and operate from Somalia. In this regard, the US continues to work with East African countries to build their capacity to counter terrorism and criminality that originates in Somalia (Frazer, 2007).

In December 2006, the UIC, by then deeply divided between radical jihadi, confused nationalists and despairing moderates, was overrun by Ethiopian tanks and Mogadishu was handed over to the TFG, while American Special Forces hunted down UIC-related terrorists but failed to find any (Samatar, 2007). In subsequent months, the TFG wasted the momentum created by the invasion as it failed to reach out to aggrieved clans that had supported the UIC, and therefore could not become the legitimate and autonomous representative of all Somalis. In a context of foreign occupation and the symbolic overnight reappearance of the hated roadblocks, it barely did anything to dispel the idea that it was more than a Somali facade for Ethiopian-American rule (ibid). Instead, its stubbornness led to an urban guerrilla movement, as Mogadishu's clans quickly took up arms. The government's tactical blunders are exemplified by the appointment of Mohamed Dheere as mayor of Mogadishu. Dheere, a greedy warlord known for his unreliability, terrorized the population throughout the last ten years and is universally loathed; his security forces, as well as Ethiopia's, have been accused by human rights organizations of horrendous excesses, including war-crimes (ibid).

Today, despite months of bloody Ethiopian repression and irregular American missile strikes against "high-value terrorist targets", the insurgency is far from quashed: almost daily, TFG forces come under attack, while Addis has run from the Somali quagmire and Washington is rapidly running out of options for stabilizing the Horn. Entire swathes of the territory have once again become no-man's land, that is, under warlord or Islamist "protection" and the number of murdered aid workers and journalists is rising rapidly. The arrival of poorly equipped, undersized African Union troops has not made the slightest difference to the pattern of violence. With more than a million people displaced, humanitarian conditions have reached their worst level since 1991 and the entire Horn of Africa is now near boiling point: man-made famine is already a reality in many communities in Eastern Ethiopia and Somalia, and tensions between Ethiopia and Eritrea, which funds the Islamist insurgency, are mounting again (Gettleman, 2006).

Notwithstanding overwhelming evidence that the rebellion is home-grown and mainly fought by disgruntled Hawiye militia members and recently radicalized youngsters, Addis and Washington have continuously blamed Al-Qaeda associates for starting the violence. The systematic diabolization of the rebels as "Al-Qaeda" has become a perfect 
self - fulfilling prophecy and blocks any serious efforts at national reconciliation (Marchal, 2004), the hardline former TFG President Yusuf used the terrorist label as an excuse not to enter into any real dialogue about power-sharing; Sheikh Ahmed Sheikh Sharif 's new government has already lost most of its credibility, begging for outside help to survive; and the decision by the White House to place Al-Shabaab on the list of terrorist organizations has further radicalized Somalia's Islamist youth. ${ }^{2}$ The appearance of suicidebombers (unheard of in Somalia before 2007) is only one of many symbols of the growing extremist tendencies among the insurgents and the population (ibid).

\section{Analyzing the situation in Somalia}

\section{Empirical evidence in Somalia contradicts the Western Conception of Failed States' simplistic statements about total lawlessness and absolute anarchy as characteristics of failed or collapsed states. Even though it is tagged a failed state, Somalia could fashion out effective local responses to human security issues.}

All too often, a dichotomy is created between "functioning" and "failed" states. Whereas the former are associated with stability and predictable political processes, the latter are equated with insecurity, chaos and "vacuums". Such labels and their associations are partially misguided and far from innocent. First, using Zartman's (1995) aforementioned definition, it is more useful to analyze a state's weakness/strength on a continuum of "state-performance" than as part of a comparison between two opposites. A state's ability to provide security, maintain territorial integrity, promote economic development, among, varies across time and space. States can strengthen as well as weaken, and collapse or failure (or "strength") are thus by no means fixed categories, but temporary conditions used to characterize the political-institutional situation in a territory (Clapham, 2001). Second, many critics argue that failing states are nothing new, but have existed for many decades as "ghost states" (Jackson, 1998). Several authors have however pointed out that

2 The Harakat Shabaab al-Mujahidin (al-Shabaab)—also known as al-Shabaab, Shabaab, the Youth, Mujahidin al-Shabaab Movement, Mujahideen Youth Movement, Mujahidin Youth Movement, and other names and variations - was the militant wing of the Somali Council of Islamic Courts that took over most of southern Somalia in the second half of 2006. Although the Somali government and Ethiopian forces routed the group in a two-week war between December 2006 and January 2007, al-Shabaab--a clan-based insurgent and terrorist group--has continued its violent insurgency in southern and central Somalia. The group has exerted temporary and, at times, sustained control over strategic locations in southern and central Somalia by recruiting, at times forcibly, regional sub-clans and their militias, using guerrilla asymmetrical warfare and terrorist tactics against the Transitional Federal Government (TFG) of Somalia and its allies, African Union peacekeepers, and nongovernmental aid organizations. On 29 February 2008, the US Government designated alShabaab as a Foreign Terrorist Organization under Section 219 of the Immigration and Nationality Act (as amended) and as a Specially Designated Global Terrorist under Section 1(b) of Executive Order 13224 (as amended). 
"state failure/collapse" is a highly subjective, flexible label that is used when it suits the international community. Many post-colonial governments, before and after 1989, not only failed to deliver socio-economic development; they also seldom controlled their entire territory, had no monopoly on violence and sometimes exported their instability, yet by no means were they considered to have "failed". For example, Siyad Barre's Somalia in the late 1980s was still recognized by the UN as a fully sovereign state, even though the regime did not speak for its people and failed to project any authority beyond Mogadishu (Doornbos, 2003). Third, the global war on terrorism also disregards the fact that many different pathways to failure exist. Socio-cultural build-up, colonial legacies, regional environment and natural resources all matter to varying degrees in Chad, Georgia, Pakistan, as do often overlooked external causes. In this respect, it is no coincidence that Western leaders are eager to point at internal dynamics while refusing to recognize how the international political economy and global power asymmetries shape states' abilities to deal with crises (Duffield, 2001). The problematic colonial legacy of completely alien state institutions and the Somali nation's dispersal over five different countries; Somalia's role as a Cold War proxy, which led to unconditional support from the West for an ever more corrupt regime; structural adjustment's disastrous impact on the national economy; and the mass inflow of arms from global black markets are all vital contributors to statefailure (Rawson, 1994). Finally, it must be noted that the supposed link between terrorism, conflict, crime and failed states is not as solid really as it is often presented. It is a truism that acephalous societies and stateless zones are rarely lawless (Giustozzi, 2005). This is because in such situations, new forms of political authority emerge organically over time and regularly provide far greater human security than a predatory state. For example, warlords may be vilified for their "greed" and links to illicit commodity trading, but as shown by Laurent Nkunda in Congo and some of the Afghani militia commanders, they can also provide much craved security and order in the regions they control (Spittaels \& Hilgert, 2008). Many war lords enjoy a real degree of local legitimacy and are at least partially responsive to the demands of the population. A fair number of militias, "self-defense units" and rebel movements within supposed failed states do engage in complicated interactions with communities involving taxation, administration and security-delivery, thereby broadening local livelihood options (Bakonyi \& Stuvoy, 2005). Similarly, it is a myth that "anarchy" automatically produces terrorist safe-havens or the breeding grounds for extremism. Most classic failed states like Central African Republic, Chad, Burma, DRC, among others, have not produced a single terrorist. Networks like Al-Qaeda need some modicum of stability and decent infrastructure or regime support to achieve their aims, not total lawlessness. Access to modern communications, transportation links, reliable financial systems, and a wide range of potential targets can be found more easily in Western societies than in African "shadow states" (Simons and Tucker, 2007: 387). Obviously, some cases of state-failure like Afghanistan and Pakistan can indeed be connected to the terrorist threat; but the determinism about the anarchyterrorism link is deeply unhelpful in understanding the real situation on the ground in failed states. 
The polarizing rhetoric and policies of America under the Bush Administration have created violent radicalism where very little existed before, as will be demonstrated for Somalia (Prunier, 2006). More fundamentally, one of the core problems of the Western Conception of Failed States lies in its deeply state-centric perspective. While the standard account recognizes that states can lose relevance and power in relation to other socio-political actors, its focus remains thoroughly on the state and the possibility of any alternative systems of rule is de facto ruled out. Put differently, the state is seen as a "given", a logical endpoint of institutional evolution. It seems as if, by definition, the international system has to be built on individual nation-states and cannot handle any blank spots on the map or more imaginative, fluid interpretations of sovereignty. The Western Conception of "Failed States" also finds that the absence of a state is uncomfortable because this raises fundamental questions about the structure of the international system of sovereign states (Clapham, 2002). Who else than the state can be responsible for debt payments and other international obligations? Moreover, security, despite significant normative shifts towards more holistic approaches, is still conceptualized as referring first and foremost to security of the state. Authority is seen through an equally narrow prism. On the one hand, the effective exercise of authority is systematically and almost only equated with state-institutions; an efficient state is seen as a necessary condition for delivering public goods. On the other hand, for the international community, legitimate authority almost automatically means a legitimate state; postconflict reconstruction always focuses on the rebuilding of state-institutions and stateauthority, and seldom explores how in local communities non-state forms of governance might be considered to be far more legitimate than classical government (Lund, 2006). In other words, the hidden assumption is that states are seen as universally viable and desirable, contrasting with the "wilderness" of non-state political governance.

Following this rationale, it is not surprising that some theorists of the global war on terrorism posit that where there is no state, "black holes" or "vacuums" abound, with terrorists, religious zealots and organized crime just waiting to fill them again. The Somali reality however suggests alternative directions are possible. Basically, the Western Conception of "Failed States" should be viewed as one-sided and serving the interest of only its users. It also leads to a disconnection with local realities, ultimately developing into a situation where the need to intervene in order to flush out terrorists ends up creating more regional insecurity. Following its crisis in 1991, Somalia was referred to as a failed state and regarded as a land of lawlessness, hunger and safe-haven for terrorists. Even though several attempts initiated by the UN to rebuild the state and to re-establish central authority have been unsuccessful, there have been several spontaneous bottom-up processes that have emerged to provide genuine and increasingly comprehensive human security to Somalis. There is an increasingly growing body of literature devoted to the remarkable success of the de facto state of Somaliland, which has overseen the revival of the pastoral economy in the Northern territories and created a stable constitutional quasidemocracy which is proving far more responsive to its inhabitants' demands than most African countries. This paper focuses not on Somaliland but on the "explosive" regions 
of Central and Southern Somalia; even there civil society's resurgence and the law-andorder project of Sharia institutions have led to dynamic governance without government, flawing the simplistic predictions of the Western conception of "Failed States". The unique Union of Islamic Courts (UIC) experiment of providing human security to the population ended abruptly with Ethiopia's 2006-07 invasion and the subsequent anti-occupation insurgency. Notwithstanding overwhelming evidence that the rebellion is home-grown, Addis and Washington continue to blame "Al-Qaeda" for the violence. By diabolizing the insurgents, the American-Ethiopian axis has been pushing moderate nationalist militants into the arms of the real (inter)national jihadists.

This paper calls for a paradigm shift from must the reductionist logic regarding the nexus between terrorism/insecurity and failed states in order to embrace an alternative strategy that conceptualizes state collapse as a series of painful but possibly essential processes of "creative destruction" with far more constructive and imaginative interactions with local dynamics and people's real needs. For it is only when bottom - up institutional responses to state-failure are taken seriously, can human security questions be addressed effectively, in Somalia and elsewhere. Historically, Somalia has always been a "state-resistant society" as anthropologists have noted. In a context of scarce resources, the four major clans and countless sub-clans have always lived in tense co-existence, refusing to accept anything more than superficial central authority, whether external or a Somali government and preferring to regulate inter-tribal relations via customary law and occasional warfare. Somalis undeniably consider themselves to be a nation, but throughout history, as well as at present, many have shown little interest in state formation, contradicting much of classical Western political theory (Lewis, 1998). Moreover, the experiences Somalia's population has had with a centralized state-system have been disastrous. While the post-independence decade was marked by spiraling corruption and governmental incompetence, (under Siyad Barre, the state predated its citizens), perpetuating impoverishment, institutionalizing insecurity and killing arbitrarily. The traditional balance of power between clans was substituted for the concentration of the monopoly of violence in the hands of the Darod-Marehan sub-clan whose abuses ultimately led to the lethal cocktail of famine and nation-wide uprisings against the old order (Doornbos, 2002). Despite the excesses of the Barre-era, it has recently been argued that the "terror" of almost two decades of state collapse should once again increase enthusiasm for the notion of a Somali state. While this article certainly does not downplay the population's post-1991 misery, such optimistic sentiments about people re-embracing the state cannot be expressed before a far more nuanced appraisal of the reality of Somali state collapse is made.

As the situation of Somalia illustrates, state failure or collapse is not necessarily coterminous with suffering, but a dynamic condition in which different undercurrents, external influences and spontaneous forms of collective life interact (Menkhaus, 2004). The struggle to survive is a daily reality, but after 1993, Somalia was not engrossed in permanent violent anarchy; on the contrary, new and old political complexes increasingly began adopting tasks that should have been carried out by the collapsed Somali state. In 
Northern Somalia, the Isaaq began constructing the proto-state of Somaliland; in parts of Mogadishu, Islamic tribunals tried to restore order through the pragmatic application of Sharia; in the remote South, clan-based militias stopped fighting to facilitate the trade that allowed communities to stave off total destitution. For outsiders, the whole of Somalia might have resembled a terrifying war zone; in reality, a complex mosaic of traditional and imaginative informal mechanisms and pacts provided a reasonable degree of stability (Marchal, 2004). As time went by, some institutions disappeared while new ones popped up, and a small number of local polities went beyond the provision of security and concentrated on more sophisticated public goods like water distribution, market regulation and basic administration on a micro-scale. The infamous inter-warlord clashes decreased markedly and commercial actors started to find ways to function in an environment of roadblocks, monetary confusion and broken infrastructure (Marchal, 2007).

\section{Conclusion}

At least, the experience of Somalia shows that the reality of state collapse is vastly more complex, contradictory and confusing than is conventionally assumed. Indeed, local responses to human insecurity can sometimes be surprisingly effective in alleviating suffering and re-introducing "governance without government" (Doornbos, 2002:99). In demonstrating much commitment to the problems of failed states, the international community must allow the bottom-up institutions that emerged in response to the dreams and grievances of the local communities to thrive. The international community must realize the important role played by local actors, religious and opinion leaders as well as institutions like the UIC. Given their legitimacy, they need to be engaged in negotiations and constructive dialogue in finding lasting solutions to the problems of human rights and security. Any effort to brand them names and antagonize them would render the fight against terrorism and the need to promote peace and security in failed states ineffective.

\section{References}

Ahmed, I., and R. Green (1999). "The Heritage of War and State Collapse in Somalia and Somaliland.' Third World Quarterly 20, No. 1, pp. 113-27.

Bakonyi, J., and K. Stuvoy (2005). "Violence and Social Order beyond the State." Review of African Political Economy, Vol. 32, No. 104, pp. 359-82.

Berger, M., and D. Borer (2007). "The Long War. Insurgency, Counterinsurgency and Collapsing States.” Third World Quarterly Vol. 28, No. 2, pp. 197-215.

\section{Center for Global Development, "On the Brink. Weak States and US National Security."}


Clapham, C. (2002). "The Challenge to the State in a Globalising World.” Development and Change, Vol. 33, No. 5, pp. 775-95.

Clapham, C. (2001). "Rethinking African States." African Security Review Vol. 10, No. 3. Available at: http://www.iss.co.za/ASR/10Noz/Clapham.html.

De Waal, A. (2004). Islamism and its Enemies in the Horn of Africa. (London: Hurst \& Co).

Doornbos, M. (2002) “Somalia: Alternative Scenarios for Political Reconstruction.” African Affairs Vol. 102, No. 406, pp. 93-107.

Doornbos, M. (2003). “State Collapse and Fresh Starts.” In J. Milliked (ed.). State Failure, Collapse and Reconstruction, (Oxford: Blackwell).

Duffield, M. (2001). Global Governance and the New Wars, (New York: Zed Books).

Fearon, J., and D. Laitin (2004). "Neotrusteeship and the Problem of Weak States." International Security, Vol. 28, No. 4, pp. 5- 43.

Frazer, J. (2007). “Testimony before the United States Senate”. Feb. 6, 2007, available at: http://www.state.gov/p/af/rls/rm/80122.htm.

Frum, D. and R. Perle (2003). An End to Evil, (New York: Random House).

Fukuyama, F. (1992). The End of History and the Last Man, (New York: Perennial).

Gettleman, J. (2006). "Islamists Calm Somali Capital with Restraint," New York Times, September 24 edition.

Giustozzi, A. (2005). "The Debate on Warlordism. The importance of Military Legitimacy." Discussion Paper. London: Crisis States Research Centre.

Ignatieff, M. (2003). Empire Lite, (London: Vintage).

Jackson, R. (1998). "Surrogate Sovereignty. Great Power Responsibility and Failed States." Institute of International Relations, University of British Columbia, Working Part No. 25 .

Kamel, K. (2007). "War without Borders.” available at

http://www.islamonline.net/servlet/Satellite?c_Article_c\&cid_1168265658525\& pagename_Zone-English Muslim_Affairs\%2FMAELayout.

Kraxberger, B. (2007). "Failed States: Temporary Obstacles to Democratic Diffusion or Fundamental Holes in the World Political Map?" Third World Quarterly, Vol. 28, No. 6, pp. 1055-71. 
Lewis, I.M. (1998). Saints and Somalis: Popular Islam in a Clan-based Society, (London: Haan Associates).

Lund, c. (2006). “Twilight Institutions", Development and Change, Vol. 37, No. 4, pp. 67384.

Marchal, R. (2004). "Islamic Political Dynamics in the Somali Civil War." In A. De Waal (ed.) Islamism and its Enemies in the Horn of Africa, (London: Hurst \& Co.).

Marchal, R. (2007). "Somalia. A New Front against Terrorism." Available at http:// hornofafrica.ssrc.org/marchal/.

Menkhaus, K. (2004). "Vicious Cycles and the Security Development Nexus in Somalia." Conflict, Security and Development, No. 2, pp. 149-65.

Menkhaus, K. (2007). "The Crisis in Somalia: Tragedy in Five Acts," African Affairs, Vol. 106, No. 424, pp. 357-90.

Prunier, G. (2006). "A World of Conflict Since 9/11: The CIA Coup in Somalia." Review of African Political Economy, Vol. 33, No. 110, pp. 749-52.

Rashid, A. (2001). Taliban: The Story of the Afghan Warlords, (London: Pan Books).

Rawson, D. (1994). “Dealing with Disintegration: US Assistance and the Somali State.” In A. Samatar (ed.). The Somali Challenge, (London: Lynne Riener).

Rotberg, R. (2004). When States Fail (Princeton, NJ: Princeton University Press).

Samatar, A. (2007). "Ethiopian Invasion of Somalia: US Warlordism and AU Shame." Review of African Political Economy, Vol. 34, No. 111, pp. 155-63.

Simons, A., and D. Tucker (2007). "The Misleading Problem of Failed States: A 'SocioGeography' of Terrorism in the Post-9/11 Era." Third World Quarterly, Vol. 28, No. 2, pp. 387-401.

Solana, J. (2003). “A Secure Europe in a Better World.” The European Security Strategy.

Spittaels, S. and F. Hilgert (2008). "Mapping Conflict Motives. Eastern DRC." Antwerp: Institute for Peace Studies, March 4, p.40.

Winkler, c. (2006). In the Name of Terrorism, (Albany, NY: State University of New York Press).

Zartman, W. (1995). Collapsed States. The Disintegration and Restoration of Legitimate Authority, (London: Lynne Rienner). 